\title{
A Systematic Review of Implementation Challenges in Public E-Procurement
}

\author{
Idah Mohungoo, Irwin Brown ${ }^{(\bowtie)}$, and Salah Kabanda ${ }^{(\bowtie)}$ \\ Department of Information System, University of Cape Town, \\ Private Bag X3, Rondebosch 7701, South Africa \\ imohungoo@hotmail.co.uk, \\ \{irwin.brown, salah.kabanda\}@uct.ac.za
}

\begin{abstract}
Challenges faced in public e-procurement implementation are not well understood despite past studies focusing on the phenomenon. This paper, which is based on a systematic literature review of academic papers, seeks to synthesize and examine the key challenges impeding public e-procurement implementation. These challenges are categorized using the TechnologyOrganization-Environment (TOE) framework as follows (1) Technological challenges: e-procurement acceptance and usage, disruptive innovation characteristic of e-procurement, use of digital signatures, security and privacy of technology and technical aspects of e-procurement (2) Organizational challenges: stakeholders' behavior, leaders' behavior, shortcomings in leadership, lack of training and skilled personnel, resistance to change, organizational power and politics and the creation of public value underlying e-procurement (3) Environmental/Contextual challenges: regulatory framework for public procurement, Small-and-Medium-Size Enterprise issues, and context of the country. Key e-procurement implementation challenges are grounded in human and contextual issues. So we recommend more case studies on public e-procurement implementation in the future.
\end{abstract}

Keywords: Public e-procurement $\cdot$ Implementation challenges $\cdot$ TOE

\section{Introduction}

Public e-procurement, commonly referred to as e-GP, is an inter-organizational system (IOS) that is intended to facilitate Government-to-Business (G2B) and GovernmentGovernment (G2G) electronic communication, information exchange, and transaction support [53]. E-procurement, which is part of public procurement reform, is a powerful tool to reduce corruption in public procurement as it reinforces transparency, accountability, and integrity in procurement functions [38]. Several developed countries such as Singapore, Australia, the UK, the USA, and Japan have successfully implemented public e-procurement systems and are reaping its benefits [37]. However, in many countries, the implementation of public e-procurement systems is perceived as daunting $[9,16,18,34,37,52]$ and it is not used to its full potential.

Sub-Saharan African countries, which on average have low scores on the corruption perception index [51], have expressed enthusiasm and interest in adopting 
e-procurement to help to curb corruption and make significant economic impacts. However, these countries face several e-procurement implementation challenges, which if not addressed, can firstly, delay the implementation process which has cost implications and; secondly, motivated leaders can lose interest and enthusiasm in driving implementation if there are too many challenges to be addressed.

Given that public e-procurement implementation is still problematic implies that implementation challenges of public e-procurement have not been well understood to date. To this end, this paper aims to provide an in-depth examination and synthesis from an information system (IS) perspective of the challenges to public e-procurement implementation using a sequentially-phased qualitative systematic literature review approach as informed by Okoli [39]. The research question, "What are the implementation challenges to public e-procurement?" will thus be addressed.

\section{Conceptual Background}

Public e-procurement implementation is a complex endeavour characterized by multiple Government-to-Business organizations (G2B), and private sector companies. These stakeholders have interests and power that can influence the outcome of the InterOrganizational Information System (IOIS) implementation [9]. Under the assumption of information system (IS) as a socio-technical endeavour, the interplay between the implementation of e-procurement and the public-private sector context is deemed to be challenging [55]. These implementation challenges should be understood in order to formulate effective strategies to contain them. Furthermore, unlike e-procurement in the private sector context, public e-procurement is expected to reflect public values such as accountability and transparency.

Public e-procurement can be understood as a hybrid of e-government, information systems, and public administration. Thus, it is highly likely that e-procurement challenges are documented in papers published in these different domains. So far, there is a lack of an integrated approach to the synthesis of e-procurement implementation challenges; and when there is an attempt to do so, it is carried out in a rather fragmented manner. Researchers have seldom stepped outside a specific discipline in e-procurement literature reviews. For example, Patrucco [43] undertook a systematic literature review on public e-procurement, focusing only on papers published in the Journal of Public Procurement. While this provides an initial view of e-procurement, such studies fail to provide a holistic view of the phenomenon given that e-procurement spans works in e-government, information systems, and public administration. To address this shortcoming, this paper offers a systematic approach to synthesizing e-procurement implementation challenges by including publications from the three domains mentioned above. The Technology-Organizational-Environment (TOE) framework [50] which is popular in studies of adoption and implementation of innovations, will be used to present the e-procurement implementation challenges. The TOE framework [50] allows the identification of the main factors influencing the adoption and implementation of innovations within different organizational contexts and therefore serves a good starting point for structuring the study - specifically the identification of technological, organizational and environmental challenges constraining e-procurement implementation. 


\section{Research Methodology}

\subsection{Research Approach}

A sequentially-phased, qualitative systematic literature review approach informed by Okoli [39] is used in this paper. It is characterized by a sequence of activities starting with article search, followed by practical screening, a full reading of papers, synthesis, and analysis.

\subsection{Data Collection}

A Desktop search of relevant articles was systematically done using a timeline from 2001 to date. Based on Google Scholar, the earliest case studies on public e-procurement were published around the year 2001. Data collection was focused consistently around the aim of the research, and the keywords used were specific to the goal of the study, as shown in Fig. 1, which depicts the different systematic passes used in the search and selection of relevant articles:

1. The first pass: articles were searched and selected from top-rated journals in the streams of information systems, e-government, and public administration, e.g.:

- Basket of eight leading Information Systems (IS) journals: European Journal of Information Systems, Information Systems Journal, Information Systems Research, Journal of Association of Information Systems, Journal of Management Information System, MIS Quarterly, Journal of Strategic Information Systems and Journal of Information Technology.

- Given that in several developing countries including those in Africa, e-procurement implementation is an important issue, the top 3 IT4D journals, i.e., Electronic Journal of Information System in Developing Countries (EJISDC), IT for Development and IT for International Development were also searched.

- IS conference proceedings focusing on emerging e-procurement implementation challenges that are found in research-in-progress in the respective aforementioned streams. The AIS top 4 conferences (ICIS, ECIS, PACIS, and AMCIS) were searched as well as IFIP conferences.

- Leading top-rated e-government journals consulted were: International Journal of E-Government Research (IJEGR), Journal of E-Government, Journal of e-Governance, Government Information Quarterly

- In public administration stream: the Journal of Public Administration and Public Administration Review were searched.

2. The second pass was a backward search after the initial search yielded few papers. The purpose of the second pass was to look for additional relevant conference papers and journal articles in other domains.

3. The third pass involved searching for adoption-focused e-procurement papers that were previously eliminated in the first-pass. This pass increased the likelihood of gathering additional secondary data on implementation challenges of e-procurement because some adoption-focused papers were case studies of post-acquisition of 
e-procurement software and thus were likely to contain facts on e-procurement implementation challenges.

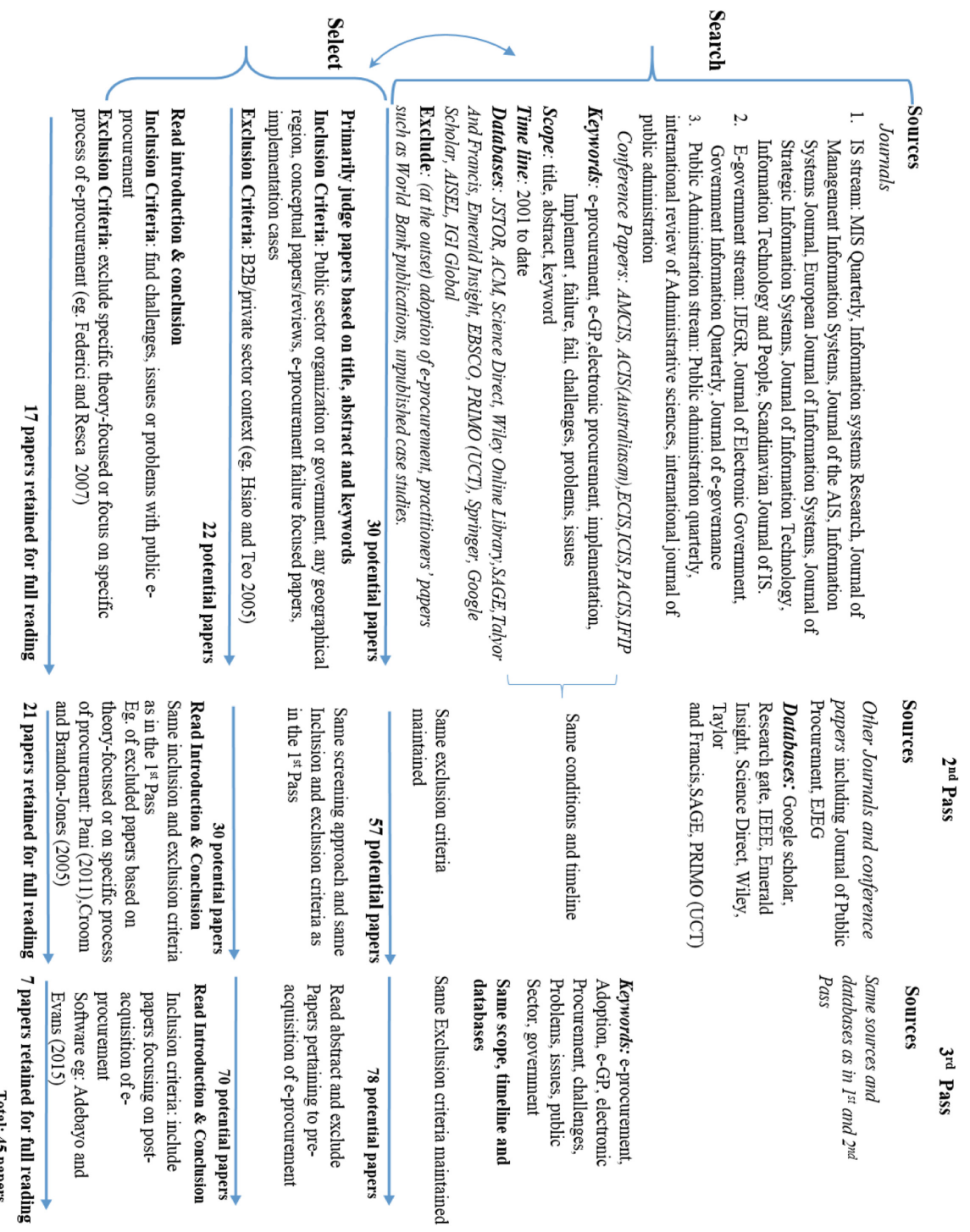

Fig. 1. Search and selection of articles (after the fashion of Gunther et al. 2017)

\subsection{Analysis}

The data corpus, which now stood at 165 articles after the previous process, was subjected to a 'Practical Screening' phase to remove irrelevant articles [39] using a 
process of inclusion and exclusion criteria. This process required the principal researcher reading the article's Title, Abstract, Introduction, and Conclusion, as explained in Table 1. Following the screening, 45 papers were retained for full reading and 34 for the final analysis as shown in Table 2. After this analysis process, relevant arguments that explain the implementation challenges faced in e-procurement implementation were extracted from the 34 papers. The key arguments were then subjected to thematic analysis in NVIVO. Emergent themes generated from common patterns in the data corpus are shown in Table 3. These themes were then structured as per the TOE framework [50] for easier conceptualization.

Table 1. Screening of papers - exclusion criteria

\begin{tabular}{|c|c|c|}
\hline Exclusion criteria & Rationale underlying exclusion & Exclusion $^{\mathrm{a}}$ \\
\hline $\mathrm{B} 2 \mathrm{~B} /$ private sector & The study focused only on public e-procurement & {$[31]$} \\
\hline $\begin{array}{l}\text { E-procurement } \\
\text { adoption focused } \\
\text { research }\end{array}$ & $\begin{array}{l}\text { All e-procurement adoption papers focusing on pre- } \\
\text { acquisition of the software were excluded because, } \\
\text { in this study, implementation is understood as a } \\
\text { stage of post-acquisition of the software }\end{array}$ & [8] \\
\hline $\begin{array}{l}\text { E-procurement } \\
\text { research papers with } \\
\text { theory-focused or with } \\
\text { focus on a specific } \\
\text { process of } \\
\text { e-procurement }\end{array}$ & $\begin{array}{l}\text { (1) Articles that focus on a specific theory were } \\
\text { discarded, for example, the economic aspects of } \\
\text { e-procurement, use of knowledge management } \\
\text { approach to understand e-procurement } \\
\text { implementation and issues, evidence of good } \\
\text { governance in public e-procurement } \\
\text { (2) Articles focusing in detail on a specific process } \\
\text { or aspect of e-procurement such as reverse auctions } \\
\text { were also excluded }\end{array}$ & $\begin{array}{l}{[14,22]} \\
{[42,48]} \\
{[12]}\end{array}$ \\
\hline
\end{tabular}

${ }^{\mathrm{a}}$ Examples of papers that are excluded as part of the screening process

Table 2. Breakdown of selected articles by publication outlet

\begin{tabular}{l|l|l}
\hline Journals & Read $^{\mathrm{a}}$ & Retained \\
\hline $\begin{array}{l}\text { AIS basket of eight leading IS journals (MISQ, ISR, JMIS, JAIS, ISJ, } \\
\text { JSIS, EJIS JIT); ICT4D Top 3 (EJISDC, IT4D and ITID) }\end{array}$ & 4 & 2 \\
\hline Information Technology \& People & 1 & 1 \\
\hline Electronic Commerce Research & 1 & 0 \\
\hline Scandinavian Journal of Information Systems & 2 & 2 \\
\hline Journal of Information Technology Teaching Cases & 1 & 1 \\
\hline IFIP Advances in IS Research, Education and Practice Proceedings & 1 & 1 \\
\hline Information Systems Frontiers & 1 & 1 \\
\hline Management and Labour Studies & 1 & 0 \\
\hline Electronic Journal of Electronic Government & 2 & 1 \\
\hline Journal of Public Procurement & 5 & 4 \\
\hline Public Administration Quarterly & 1 & 1 \\
\hline Emerging Markets Finance and Trade & 1 & 1 \\
\hline & & (continued)
\end{tabular}


Table 2. (continued)

\begin{tabular}{l|l|l}
\hline Journals & Read $^{\mathrm{a}}$ & Retained \\
\hline International Review of Administrative Sciences & 1 & 1 \\
\hline International Journal of Public Administration & 2 & 2 \\
\hline Journal of Purchasing and Supply and Management & 1 & 1 \\
\hline International Journal of Production and Operations Management & 1 & 1 \\
\hline Journal of Enterprise Information Management & 1 & 0 \\
\hline Strategic Change & 1 & 1 \\
\hline AIS Conference Proceedings (ICIS, ECIS, PACIS, AMCIS) & 5 & 4 \\
\hline Other Conference proceedings and papers & 8 & 6 \\
\hline Vikalpa: Journal for Decision Makers & 1 & 1 \\
\hline Advances in e-Government, Digital Divide \& Regional Development & 3 & 2 \\
\hline & 45 & 34 \\
\hline
\end{tabular}

${ }^{\mathrm{a}}$ Full length paper read

Table 3. Empirical findings of public e-procurement implementation challenges

\begin{tabular}{|c|c|c|}
\hline & Implementation challenges & Authors \\
\hline \multirow[t]{10}{*}{ Technological } & Acceptance and usage issues & {$[3,5,7,9,16,20,24,33,37,55]$} \\
\hline & Disruptive nature of e-procurement & {$[4,35]$} \\
\hline & Digital/Electronic signature & {$[17,40]$} \\
\hline & IT security issues & {$[23,37,46,52]$} \\
\hline & Complicated system & {$[34]$} \\
\hline & Multi-platform & {$[5,17]$} \\
\hline & Lack of system integration & {$[2,16,17,23,34,36,46,47]$} \\
\hline & $\begin{array}{l}\text { Shortcomings in online product } \\
\text { catalogue }\end{array}$ & {$[16,34]$} \\
\hline & Challenges for software specifications & [46] \\
\hline & $\begin{array}{l}\text { Inadequate IT \& networking } \\
\text { infrastructure }\end{array}$ & {$[2,46]$} \\
\hline \multirow[t]{11}{*}{ Organizational } & Stakeholders' issues & {$[15,33,36]$} \\
\hline & Leaders' behavior & {$[56]$} \\
\hline & Shortcomings in leadership & {$[24,34,36]$} \\
\hline & Change management problems & {$[1,24]$} \\
\hline & Lack of a project champion & {$[56]$} \\
\hline & Lack of training and skilled personnel & {$[17,24,30,34,46,52]$} \\
\hline & Resistance to change & {$[2,5,16,28,53,56]$} \\
\hline & Slow-to-change culture & {$[6,36]$} \\
\hline & Departmentalism & [6] \\
\hline & Major reforms through ICT & {$[36,45]$} \\
\hline & Value-driven outcome & {$[6,37,53]$} \\
\hline \multirow[t]{3}{*}{ Environmental } & Regulatory frameworks & {$[21,29,57]$} \\
\hline & SME issues & {$[3,17,24,36,41,54,55]$} \\
\hline & Country context & {$[46,54,56]$} \\
\hline
\end{tabular}




\section{Findings and Discussion}

\subsection{Technological Challenges}

Key technological challenges that deserve due attention given that they are tied with human and contextual issues are acceptance and usage issues, disruptive innovation, digital signature, and IT security issues. The remaining ones pertain to the technical aspects of e-procurement, and they are grouped as 'other technological challenges' in the discussion below.

Acceptance and Usage Issues. The findings indicate that acceptance and usage is an important challenge for e-procurement. The reasons were vast, ranging from technocentric issues to broader dimensions such as dissatisfaction with e-procurement systems that do not meet the needs of users with the consequence of emergence of multiple workarounds [37]; Lack of user-friendliness of e-procurement [5, 34]; Complicated systems [5, 20]; Inability to enlist sufficient suppliers in a timely manner to encourage IS use [53]; The use of technology which is in tension with cultural histories of IT usage, bureaucratic processes and business practices [55].

Disruptive Innovation. E-procurement is viewed as a disruptive innovation [4, 35] that can drive a radical transformation, thereby uprooting some institutionalized work practices. It may conflict with the slow-to-change culture of G2G stakeholders of e-procurement [36].

Digital Signature/Electronic Signature. Costa, Arantes, and Tavarez [17] found that digital signature, which is mandatory for e-procurement, is complex to use and is costly, whereas Ojha and Pandey [40] found that the digital signature is a means of excessive security on e-procurement causing exclusion of some suppliers. Beyond these techno-centric aspects, the use of digital or electronic signatures can directly clash with the stakeholders' values, beliefs, and customs associated with manuscript signatures [49].

IT Security issues. Mc cue Roman [37] found that IT security and authenticity was the major challenge in e-procurement as stakeholders had concerns and demanded more reassurance with regards to the robustness of the security aspect of the e-procurement platform in terms of IT security measures implemented for access control, backup and recovery [22].

Other Technological Challenges. Other technological challenges include amongst others, system integration problems with legacy and suppliers' systems, which is an important technical issue and is underpinned by the use of different enterprise software systems to handle each stage of the procurement cycle [2, 34]; the presence of multiplatforms for tendering which confuse bidders [5]; excessively complicated systems and; different data formats $[5,17]$. 


\subsection{Organizational Challenges}

Organizational issues in e-procurement implementation are interlinked. Lack of a project champion and problems of change management are associated with shortcomings in leadership. Resistance to change is explained alongside other challenges, including departmentalism, major reform through ICT and organizational power and politics.

Stakeholders' Issues. Drawing from e-government studies, scholars advocated the importance of sustained engagement of stakeholders in e-government implementation to enhance IS acceptance [13]. The review findings indicate a lack of stakeholder engagement in e-procurement implementation [15, 33, 36]. Scholars advised implementers to convince stakeholders to get their buy-in to improve IS usage [15, 34, 52].

Leaders' Behavior. Williams-Elegbe [56] argues that public sector leaders often exhibit unethical behaviours which can hamper the implementation of e-procurement. Leaders' behavior was associated with the failure of past e-government projects [25, 28]. Some leaders played overt rationality whilst having buried agendas [18], and obfuscated the objectives behind e-government to achieve their interests [44].

Shortcomings in Leadership. In some cases, public sector leaders are genuinely committed to achieving success in e-procurement implementation, but they may lack leadership skills [24, 34] to address change management problems [1, 24], and become good project champions which is a critical success factor in any e-government implementation [56].

Lack of Training and Skilled Personnel. Inadequate staff training on e-procurement results in low e-procurement usage ([17, 24, 34]). Furthermore, lack of skilled ICT personnel on-site to deal with technical e-procurement issues, service-level agreements, and operationalization of the private-public partnership model of e-procurement implementation are serious impediments to e-procurement implementation ([30, 40, 46]).

Resistance to Change. Resistance to change is a significant e-procurement implementation challenge with multiple underlying causes. Small and Medium Enterprises (SMEs) resist to e-procurement because they require equitable access to government business [55]. Besides, the reforms driven through e-government projects often conflict with reforms prescribed in public policies which follow the New Public Management (NPM): Somasundaram [46] found that centralization ideas underlying e-procurement, conflicted with the decentralization ideology [46] which challenged the norms of Danish local authorities; while Barca and Cordella [6] found that e-procurement faces departmentalism challenges which are perceived as a strong cultural and organizational barrier [6]. Resistance to change is also grounded in organizational power and politics [2] that shadowed the benefits of e-procurement: purchase managers were unwilling to use e-procurement despite agreeing with the economic arguments of cost-saving, and reduction of direct procurement costs related to the new e-procurement platform [29].

Value-Driven Outcome. Unlike the private sector, implementation of public e-procurement is expected to reflect public values of transparency, integrity, and accountability [6, 37, 53]. If the government expects e-procurement to enforce 
accountability and transparency for good governance, implementation will be called a success when stakeholders make sense of these public values and embrace them, which is indeed challenging to achieve.

\subsection{Environmental Challenges}

E-procurement implementation yielded different outcomes in different countries, with varying success in Italy, Australia and, Scotland [55] but failure in Turkey whereby expected results of increased competition and lower procurement prices were not achieved [27]. Regulatory frameworks, SME issues, and the country context are among the key environmental challenges that have been found as relevant in this review.

Regulatory Framework. Public procurement regulatory frameworks may present significant challenges in e-procurement implementation [21, 29, 57], the most pertinent ones being the mandated use of e-procurement; and the laws governing the use of digital signatures which limits the participation of SMEs in government bids.

SME Issues. The difficulties that SMEs face with respect to e-procurement and public procurement process are amongst others: exclusion of SMEs [17, 54]; SME lack of investment in ICT infrastructure [3, 27]; lack of financial capabilities and contract guarantees as needed by government procurement; insufficient competence in terms of standards and technical qualifications set by the market [41]. The business context of a country, therefore, poses a challenge to the success of e-procurement implementation especially if SMEs make a substantial contribution to the GDP. In Turkey, exclusion of SMEs negatively affected competition in the market and caused a rise in prices which ran contrary to the proclaimed expectations from public e-procurement implementation [27].

Country Context. The federal-state dynamic, especially in big countries has been found to be a key challenge for e-procurement [46], whereby the best practices underlying the success of e-procurement in a specific state were not replicated to other states as it could compromise the degree of autonomy of the other states. Considering cultural challenges, some developing countries continue with corrupt practices despite e-procurement because corruption has become entrenched in the culture. Overt and covert corruption has become the norm in these countries [56]. It is challenging to achieve the expected objectives of e-procurement, i.e., transparency, accountability and curbing corruption.

Other Country-Related Challenges. E-procurement which is a G2B e-government project and is based on e-commerce technology, faces similar country-context challenges of e-government implementation in developing countries such as poor ICT infrastructure, language barriers, impact of local customs, norms and national culture, lack of financial instruments such as debit/credit card to facilitate e-commerce [11, 32]. These contextual challenges are beyond the scope of this review but are directly relevant to e-procurement.

The key e-procurement implementation challenges are interlinked, as presented under the TOE typology [50] in Fig. 2. The arrows indicate the relationship between the key challenges identified and discussed in this study. 


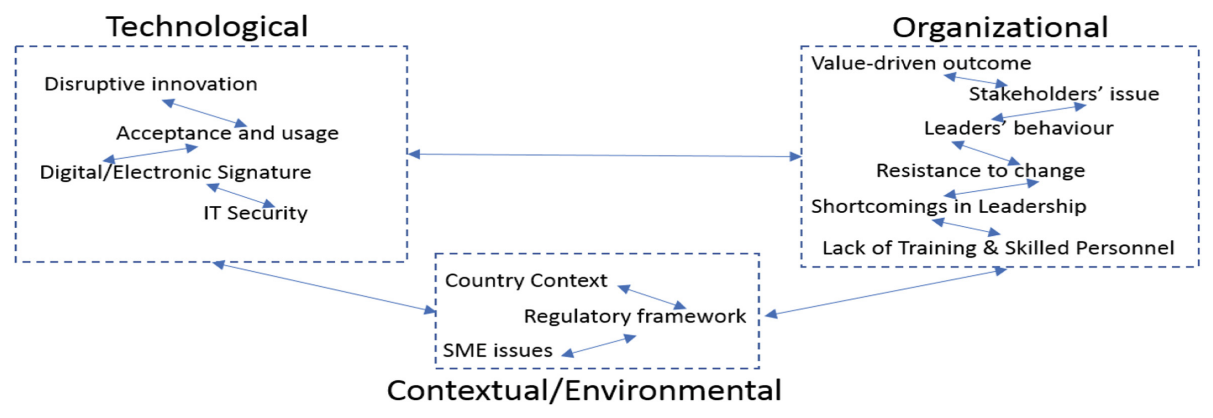

Fig. 2. Inter-relationship of key e-procurement implementation challenges

\section{Conclusion}

This study aimed to synthesize and examine the implementation challenges to public e-procurement. A multi-disciplinary qualitative systematic literature review was done based on papers published in the e-government, information systems and public administration domains. The study identified (1) technological challenges of acceptance and usage, e-procurement as a disruptive innovation and technical issues with e-procurement; (2) organizational challenges of stakeholders' issues, leadership, inadequate training, and skilled personnel, resistance to change and value-driven outcome and (3) key environmental factors of procurement regulatory framework, the country context and, the problems faced by SMEs. These findings enlighten practitioners and policy implementors with information on the possible hindrances to successful e-procurement implementation. Building upon this awareness, future studies can embark on explaining the causal mechanism of these challenges and how best to address them in a context-specific manner. This research work focused on e-procurement implementation challenges as a whole and excluded challenges pertaining to specific eprocurement processes such as e-tendering and e-reverse auction. The proposed framework in this paper can be used in future case studies to examine e-procurement implementation challenges under each focus area of the TOE [50] and their relationship.

\section{References}

1. Al-Moalla, A., Li, D.: Organisational issues with electronic government procurement - a case study of the UAE. EJISDC 41(3), 1-18 (2010)

2. Adebayo, V.O., Evans, R.D.: Adoption of E-procurement systems in developing countries: a Nigerian public sector perspective. In: 2nd International Conference on Knowledge-Based Engineering and Innovation. IEEE, Tehran, pp. 356-376 (2015)

3. Alomar, M.A., Visscher, C.: E-public procurement: which factors determine its acceptance by small to medium-sized enterprises and large companies in Belgium? Int. Rev. Adm. Sci. 85(2), 356-376 (2017)

4. Barahona, J.C., Elizondo, A.M.: The Disruptive innovation theory applied to national implementations of E-procurement. EJEG 10(2), 107-119 (2012) 
5. Barahona, J.C., Elizondo, A., Santos, M.: The dilemma of public E-procurement in Costa Rica: case on the duality of technological platforms and implementation models. J. Inf. Technol. Teach. Cases 5(2), 57-64 (2015)

6. Barca, C., Cordella, A.: Seconds out, round two: contextualising e-government projects within their institutional Milieu - a London local authority case study. Scand. J. Inf. Syst. 18(2), 5 (2004)

7. Brandon-Jones, A., Kauppi, K.: Examining the antecedents of the technology acceptance model within E-procurement. Int. J. Oper. Prod. Manag. 38(1), 22-42 (2018)

8. Bof, F., Previtali, P.: Organisational pre-conditions for E-procurement in governments: the Italian experience in the public health care sector. EJEG 5(1), 1-10 (2007)

9. Bromberg, D., Manoharan, A.: E-procurement implementation in the US - Understanding progress in Local Government. Public administration Quarterly 39(3), 360-392 (2015)

10. Boonstra, A., Vires, J.D.: Managing stakeholders around inter-organizational systems: a diagnostic approach. J. Strat. Inf. Syst. 17, 190-201 (2008)

11. Bwalya, K.J., Mutula, S.: A conceptual framework for e-government development in resource-constrained countries: the case of Zambia. Inf. Dev. 32(4), 1183-1198 (2016)

12. Cabral, L., Ferreira, L., Dias, G.P.: Adoption of reverse auctions in public E-procurement: the case of Portugal. In: 11th Iberian Conference (CISTI), pp. 1-5. IEEE, Las Palmas (2016)

13. Chan, C.M.L., Pan, S.L.: User engagement in e-government systems implementation: a comparative case study of two Singaporean e-government initiatives. J. Strat. Inf. Syst. 17, 124-139 (2008)

14. Croom, S.R., Brandon-Jones, A.: Key issues in E-procurement: procurement implementation and operation in the public sector. J. Public Procure. 5(3), 367-387 (2005)

15. Chomchaiya, S., Esichaikul, S.: Consolidated performance measurement framework for government E-procurement focusing on internal stakeholders. Inf. Technol. People 29(2), 354-380 (2016)

16. Croom, S., Brandon-Jones, A.: Impact of eprocurement: experiences from implementation in the UK public sector. J. Purch. Supply Manag. 13(4), 294-303 (2007)

17. Costa, A., Arantes, A., Tavares, L.: Evidence of the impacts of public E-procurement: the Portuguese experience. J. Purch. Supply Manag. 19, 238-246 (2018)

18. De', R., Sarkar, S.: Rituals in E-Government implementation: an analysis of failure. In: Wimmer, M.A., Chappelet, J.-L., Janssen, M., Scholl, Hans J. (eds.) EGOV 2010. LNCS, vol. 6228, pp. 226-237. Springer, Heidelberg (2010). https://doi.org/10.1007/978-3-64214799-9_20

19. Elbanna, A.: From intention to use to actual rejection: the journey of an E-procurement system. J. Enterp. Inf. Manag. 23(1), 81-99 (2010)

20. Engstrom, A., Wallstrom, A., Sangari, E.: Implementation of public E-procurement in Swedish government entities. In: Proceedings of the IMCSIT, pp 315-319 (2009)

21. Faridian, P.: Innovation in public management: is public eprocurement a wave of the future? A theoretical and exploratory analysis. Int. J. Public Adm. 38(9), 654-662 (2015)

22. Federici, T.R., Resca, A.: Managing a widespread E-procurement implementation in public healthcare. In: MCIS 2007 Proceedings, vol. 5. MCIS, Italy (2007)

23. Fedorowicz, J., Gelinas, U., Gogan, J., Williams, C.: E-Government, E-Procurement, and E-Payments: data sharing issues associated with an appreciating database. In: AMCIS 2004 Proceedings, vol. 137. AMCIS, New York (2004)

24. Gasco, M., Cucciniello, M., Nasi, G.: Determinants and barriers of E-procurement: a European comparison of public sector experiences. In: Proceedings of the 51st Hawaii International Conference on System Sciences (2018)

25. Goldfinch, S.: Pessimism, computer failure, and information systems development in the public sector. Public Adm. Rev. 67, 917-929 (2007) 
26. Günther, W.A., Mehrizi, M.H.R., Huysman, M., Feldberg, F.: Debating big data: a literature review on realizing value from big data. J. Strat. Inf. Syst. 26(3), 191-209 (2017)

27. Gurakar, E.C., Tas, B.D.: Does public E-procurement deliver what it promises? Empirical evidence from Turkey. Emerg. Mark. Finance Trade 52(11), 2669-2684 (2016)

28. Heeks, R.: Information systems and developing countries: failure, success and local improvisations. Inf. Soc. 18(2), 101-112 (2002)

29. Henriksen, H.Z., Mahnke, V.: E-procurement adoption in the Danish public sector: the influence of economic and political rationality. Scand. J. Inf. Syst. 17(2), 85-106 (2005)

30. Hashim, R., Mazuki, M.A.: Electronic procurement (E-procurement) implementation in municipalities: lessons learned. In: E-procurement Management for Successful Electronic Government System, pp. 220-238. IGI-Global (2013)

31. Hsiao, R.L., Teo, T.: Delivering on the promise of E-procurement. MIS Q. Exec. 4(3), 4 (2005)

32. Kabanda, S., Brown, I.: E-commerce enablers and barriers in Tanzanian small and medium enterprises. EJISDC 67(7), 1024 (2015)

33. Kaliannan, M., Raman, M., Dorasamy, M.: E-procurement adoption in the Malaysian public sector: organizational perspectives. In: 13th Enterprise Distributed Object Computing Conference Workshops, Auckland, pp. 189-194 (2009)

34. Krogstie, J.: Introduction of a public sector E-procurement solution: lessons learned from disappointing adoption. In: Avison, D., Kasper, G.M., Pernici, B., Ramos, I., Roode, D. (eds.) Advances in Information Systems Research, Education and Practice. ITIFIP, vol. 274, pp. 203-214. Springer, Boston, MA (2008). https://doi.org/10.1007/978-0-387-09682-7-9_17

35. Lyytinen, K., Rose, G.: The disruptive nature of information technology innovations: the case of Internet computing in systems development organizations. MIS Q. 27(4) (2003)

36. MacManus, S.A.: Understanding the incremental nature of E-procurement implementation at the state and local levels. J. Public Procure. 2(1), 5-28 (2003)

37. McCue, C., Roman, V.: E-procurement: myth or reality? J. Public Procure. 12(2), 221-248 (2012)

38. Neupane, A., Soar, J., Vaidya, K.: An empirical evaluation of the potential of public E-procurement to reduce corruption. AJIS 18, 21-44 (2014)

39. Okoli, C.: A guide to conducting a standalone systematic literature review. Commun. Assoc. Inf. Syst. 37 (2015)

40. Ojha, S., Pandey, I.M.: E-procurement project in Karnataka: a case of public private partnership. Vikalpa 39, 113-118 (2014)

41. Ortuzar, G.B., Sevillano, E., Castro, C., Uribe, C.: Challenges in Chilean E-procurement system: a critical review. In: Digital Governance and E-Government Principles Applied to Public Procurement, pp. 170-190. IGI Global (2017)

42. Pani, M.R., Agrahari, A., De, S.K.: Literature review and research issues in E-procurement. Manag. Labour Stud. 36(3), 225-246 (2011)

43. Patrucco, A.S., Luzzini, D., Ronchi, S., Essig, M., Amman, M., Glas, A.: Research perspectives on public procurement: content analysis of 14 years of publications in the journal of public procurement. J. Public Procure. 17(2), 229-269 (2017)

44. Quinta, N.N., Islam, S.: Challenges to the successful implementation of e-government initiatives in sub-Saharan Africa: a literature review. EJEG 11(2), 253 (2013)

45. Somasundaram, R.: Diffusion of eprocurement in the public sector - revisiting centralization versus decentralisation, debates as a twist in the tale. In: ECIS Proceedings, Turku, Finland, pp. 1546-1556. ECIS (2004)

46. Somasundaram, R.: Challenges in implementation of E-procurement in the indian government. In: Ari-Veikko, A. (eds.) Electronic Government: Concepts, Methodologies, Tools, and Applications, pp. 2106-2121. IGI Global (2008) 
47. Scriven, G.: Interoperability in Australian government E-procurement - strategy versus reality. In: 7th PACIS 2003 Proceedings, pp. 1436-1454. PACIS, Adelaide (2003)

48. Siriluck, R.: Critical governance concerns of Thailand e-government procurement. In: CONF-IRM 2012 Proceedings, vol. 52 (2012)

49. Srivastava, A.: Resistance to change: six reasons why businesses don't use e-signatures. J. Electron. Commer. Res. 11(4), 357-382 (2011)

50. Tornatzky, L.G., Fleischer, M., Chakrabarti, A.K.: The process of Technological Innovation. Lexington Books (1990)

51. Transparency International (2018). https://www.transparency.org/news/feature/cpi2018-sub saharan-africa-regional-analysis. Accessed 10 Mar 2019

52. Vaidya, K., Sajeev, A., Callender, G.: Critical factors that influence E-procurement implementation success in the public sector. J. Public Procure. 6(1), 70-99 (2006)

53. Vaidya, K., Campbell, J.: Multidisciplinary approach to defining public E-procurement and evaluating its impact on procurement efficiency. Inf. Syst. Front. 18, 333-348 (2016)

54. Walker, H., Brammer, S.: The relationship between sustainable procurement and E-procurement in the public sector. Int. J. Prod. Econ. 140, 256-268 (2012)

55. Williams, S., Hardy, C.: Public E-procurement as socio-technical change. Strat. Change 14, 273-281 (2005)

56. Williams-Elegbe, S.: Beyond uncitral: the challenges of procurement reform implementation in africa. Stellenbosch Law Rev. 25(1), 209-224 (2014)

57. Wirtz, B., Lütje, S., Schierz, P.G.: An empirical analysis of the acceptance of E-procurement in the german public sector. Int. J. Public Adm. 33(1), 26-42 (2009) 